Vesna Polovina*

University of Belgrade

Faculty of Philology

Gordana Jelić

Academy of Technical and Art Applied Studies Belgrade

School of Applied Studies for Information

and Communication Technologies
811.163.41:316.774

Originalni naučni rad

Primljen: 19.05.2020

Prihvaćen: 11.10.2020

\title{
SHORTENING AND CLIPPING IN SERBIAN TEXT MESSAGING
}

The analysis of shortening and clipping in text messaging is of interest both from sociolinguistic standpoint since it is considered as a feature of this type of texts, often critized as having a negative impact on the literacy in young people, and from general linguistic aspect of a (non)morphological process of shortening words and expressions. The majority of analyzed cases that occur in the corpus of Serbian text messages show that it is indeed the young texters who use shortened forms of words more often than people over thirty years of age, but the young generation also use them in line with spontaneous oral language and with usage of quite a few shortened forms as prescribed by the orthographic rules, than some deviant, irregular ways. Rather, these shortenings have the roles of confirming ingroup relations, spontaneity and easy everyday communication between friends, reflecting informality of spontaneous, everyday oral communication, and often showing subtlety in implicit knowledge of the language rules.

Key words: text messages, Serbian, shortening, clipping, elision

Introduction. In many languages, as is the case with the Serbian language, derivation and composition are the most productive processes in terms of the number of new words that are or could be created. Some other processes are considered to be less productive. This might apply to shortening, blending, conversion, word loaning from other languages. In this paper we pay special attention to shortening and clipping in text messaging for several reasons. We will use these terms in the paper

polovina.v@gmail.com 
Vesna Polovina / Gordana Jelić

as neutral cover terms for various types of shortenings (similarly to Bieswanger, 2009)

From a sociolinguistic point of view, the fact that different types of shortenings and clippings in text messaging are often negatively characterized in relation to standard, especially written language, we believe that such popular views on one variety must be considered in light of the facts about a range of other varieties of language. In this study, we analyze shortening of words in Serbian text messaging, mainly in relation to the written and spontaneous spoken language. But the significance of studying this morphological process has also bearing on the questions of prescriptivism, relations between language varieties in general, the cleavage between oral and spoken language (Blasco, M. et C. Bodelot, 2017) etc., which are questions that will be indirectly touched upon in this study as well.

As a general linguistic question, the shortening of words and expressions, although a common occurrence in languages, has a controversial status in linguistic theory. Namely, some linguists, such as Mel'cuk (2006: 310), or Bauer (Bauer, 2004: 63), argue that the occurrence of shortening (clipping) does not represent productive morphological processes which create new words, but non-morphological phenomena. For instance, Mel'cuk talks about "techniques" in "word-creation" process. Those techniques, according to him, are clipping, blending, acronymization and analogical formation. They "expand the lexical stock by creating new lexemes" but they are diachronic as opposed to genuine morphological processes. Although creative, these processes are not systemic - the abbreviated word has no new meaning, remains within the same type/class of word as the full form of the word, the form in written language is often inconsistent with expected orthographic rules of a given language, etc. In short, it is not possible to predict the creation of shortenings, and such cases are not subject to some "logical" rules (e.g., morpho-phonological).

However, there are indications that some of these claims should not be fully adopted. Examples of meaning change can be found, so in English fan in the sense of "devotee" differs from fanatic, exam can refer only to "school exam", but not to "medical examination", or the short form can collocate with another word, whereas the full form cannot (e.g. "gym shoes", but not "gymnasium shoes"), pram has almost completely lost its connection with the perambulator, chacha (<muchacha) in Spanish denotes "girl", and also the instrument - "cleaner". There are similar cases in other languages, and we 
mention one in Serbian - teta ("auntie") is a hypocoristic of tetka ("aunt"), and also a "person who looks after the children, a nanny" (e.g. Imamo novu tetu - "We have a new nanny", but we cannot say *Imamo novu tetku - "We have a new aunt"). However, the degree of semantic differences between the full word form and shortened forms is generally not as pronounced as in the above examples, so although these are interesting cases, the great majority of shortened forms seem to have either the same meaning or some type of pragmatic or sociolinguistic nuancing of meaning.

This slightly different meaning is often termed as "stylistic", i.e., the use of the shortened form of a word connotes belonging to a certain discourse community, usually peer community, or is a kind of professional jargon, or both. The meaning of closeness, intimacy is also evident in the fact that many languages create diminutive and hypocoristic words by shortening, sometimes with additional affixation (as in Serbian krimić - "crime story", fotka - "photography", (Jovanović, V. 2015). A feature of humour is also attributed to them, and this is especially evident in colloquial speech, in the slang of young people, or certain types of communication - within family and close friends, among young people, or in talking to children, and the like (Plag, 2002: 146-150). Hence the shortening and clipping are said to belong to "expressive morphology" or "extragrammatical morphology" (Zwicky and Pullum, 1987: 330).

In addition to pointing to specific domains of communication that are characterized by who the interlocutors are, it is often indicated that shortened word forms occur primarily in oral communication, but some are characteristic only of the written medium (as in English $\mathrm{Dr}$., Ms., etc.). Studies are sometimes based primarily on written language material - dictionaries, grammars, written press, etc. where colloquial oral forms are also recorded (Gonzales, 2018: 736). However, they do not represent the dominant "domains" that are claimed to give the largest number of shortenings. The same is true for contrastive research (Jovanović, 2015; Gonzales, 2018) with focus on systemic differences between languages (mainly English and some other language), determining the types of shortenings, their productivity, the relationship between shortened and full forms of lexemes and expressions and their semantics, morphosyntactic and phonological constraints, phonemic-graphemic features.

Since writing messages, as we have already mentioned, is most often an informal type of communication, between friends, or people who are close 
to each other, in such communication it is possible to see how the speakers themselves transmit some features of the spoken language into the written language. This is especially important in the case of shortened expressions largely deriving from everyday, informal language, and that is the starting point of this paper. Some previous research showed that the shortening of words and expressions is, although in no way an unusual process, a common occurrence in electronic communication, and that it has become a "specific feature of the language of electronic communication". Thus, Radić-Bojanić (2007: 60) points out, based on the analysis of the discourse of electronic chat rooms, that clippings and abbreviations can be considered a kind of "professional jargon", since they were coined and now used exclusively by participants in various types of electronic communication.

However, neither written language itself nor some other styles (registers) are devoid of this phenomenon. When we look at the orthography of the Serbian language, abbreviated spelling of words and expressions is quite common and acceptable. Some shortenings, clippings, abbreviations have existed for centuries (for example, in grammars, in religious texts), and new ones are redefined for different domains of life (examples are easy to find - e.g. increasing the number of municipalities in our country at one point of time also meant increasing the number of abbreviations on license plates). In scientific texts, on the other hand, there are precise rules on how to deal with abbreviations in published work, and if they are not generally known, they must be explained at the first use and then used consistently in the text. Given such well-known phenomena in various other varieties of language, it is clear why the epithet "a kind of professional jargon" has been attributed to shortening in electronic communication, even though the epithet "professional" does not suit everyday informal communication or messages. In other words, truncation is not a feature of text messages only, and whether there are any really message-specific shortenings, and to what extent they are a feature of the language of written messages over the phone, we will see in the analysis that follows.

The frequency of shortened word forms. What is immediately noticeable when looking at the shortenings in our corpus, consisting of 20.000 messages ( 10.000 provided by young people and 10.000 by people over thirty), is that they are more frequent in informal communication among young people than in the adult text messaging, so our further presentation of shortening and clipping will refer primarily to the messages 
of young people, and only in some cases we will compare young and adult text messages, when we think that it is important enough in order to draw certain conclusions. We will group them later on into form-functional categories. Our first observations deal with their frequency.

The analysis of the corpus of short messages in the Serbian language shows that the use of shortened forms is not nearly as frequent as it seems at first glance. In a small sample of messages (202) there were a total of 21 abbreviated forms of the following type: fixni ( $>$ fiksni [telefon] - landline phone), inst ( $>$ instagram), tb ( $>$ tebe - "you" in genitive case), vrv ( $>$ verovatno - "probably"), nmg ( $>$ ne mogu - "I can't), TV, geos (>geo + os - " geography">), bus, DZ ( "Dom zdravlja" - "Health Center"), saraj. cevap ( > sarajevski ćevap - "Sarajevo ćevap"), taxi ( > taksi), info ( > informacija - "information"), itd. ("etc."); then 27 tokens such as: ajde ( > hajde "c'mon") jel, dal, (question particles $l i, d a+l i$, short form je of verb be) and about 7 abbreviations of the type: TV, eg, din, min, etc. Some of them are more frequent and some occur rarely, as we will see in the further analysis.

Such a small number (55 altogether) of shortened words may come as a surprise at first glance, since English and its shortenings and clippings are often mentioned, and they seem not only more numerous, but also impacting other languages. However, as one author (Bieswanger, 2009) has shown by comparing German and English written messages, there are significant differences between these two languages: apart from the initialisms, which are more common in German than English (0.13 per message in German), different other types of abbreviations are far less numerous than in English: since the number of tokens is divided by the number of messages, the results showed that there were 5.57 abbreviations per message in English, while in the German corpus that number was 0.86. In a part of our corpus in Serbian, a sample of 202 messages written by young people, that number was 0.27, which is far less than in English and German. Although such measurement, and consequently comparison, may depend on a number of factors: the type of authors of messages, situations in which and about which they correspond, topics covered by messages, so that the results could change by taking another set of messages, we nevertheless consider our comparison relevant as an indicator of the Serbian text messaging: the messages we chose for this measure were written by young people (high school teenagers and university students), dealing with common topics (Ling, 2005). 
Vesna Polovina / Gordana Jelić

The form and function of shortenings. In the following text, we will show the different types of shortenings and clippings that appear in our corpus, first by the form: vowel elision, final elision, initial and medial elision, as well as by origin: standard elision, and clippings loaned from English.

Elision of vowels. What this group of shortenings has in common is that they were created by the elision of the vowels, so only consonants remained in the word, facilitating its recognition and understanding.

Table 1. Shortened and full forms of some modal verbs and expressions and modifiers:

\begin{tabular}{|l|l|l|l|l|l|l|l|}
\hline \multicolumn{2}{|l|}{ Shortened form } & \multicolumn{2}{l|}{ Full form } & \multicolumn{2}{l|}{ Shortened form } & \multicolumn{2}{l|}{ Full form } \\
\hline Msm & 142 & mislim & 124 & nzm & 10 & ne znam & 260 \\
\hline Mrm & 5 & moram & 192 & nmp & 3 & $\begin{array}{c}n \text { e m a m } \\
\text { pojma } \\
\text { verovatno }\end{array}$ & 66 \\
\hline Nrv & 12 & naravno & 73 & vrv & 19 & & \\
\hline Nmg & 17 & ne mogu & 182 & & & & \\
\hline
\end{tabular}

msm > mislim ("think"); mrm > moram ("must"); nmg > ne mogu ("I cannot), nzm > ne znam ("I don't know") nmp > nemam pojma ("I have no idea") $n r v>$ naravno ("of course"), vrv $>$ verovatno ("probably").

The numbers listed in Table 1 refer only to what appears in the messages of young people. We found only one example of these shortenings in adults over thirty years of age in the following message:

$(\mathrm{O} 1)^{1}$ < ajde mi kupi nesto za veceru nmg jedem.ono. Plasi me i nzm staje> ("come buy me something for dinner can't eat. that. It scares me and I don't know what it is")

As can be seen from Table 1, the verb msm ( $>$ misliti - "to think" usually shortened when used in the sense: "I mean") is very frequent, while other verbs: $\mathbf{m r m}>$ moram "I must", $\mathbf{n m g}>$ ne mogu "I can't", nzm >

$1 \mathrm{M}$ and $\mathrm{O}$ in examples refer to messages taken from young people $(\mathrm{M}-$ mladi "young") and adults (O - odrasli "older, above thirty"), respectively. 
ne znam "I don't know", nmp > nemam pojma "I have no idea" as well as modifiers: nrv > naravno "of course", vrv > verovatno "probably" are relatively rarely shortened, even though they are not infrequent words in the corpus.

The verbs think and know are frequent words not only in colloquial language and messages but also in many other texts. In this shortened form, the verb "to think" is used almost exclusively as a discourse marker (Polovina, 2019:112-120). Here we will only mention that the shortened form fully corresponds to the colloquial pronunciation of this verb form as a discourse marker $/ \mathrm{misim} /$ or $/ \mathrm{m} ə \mathrm{~s} ə \mathrm{~m} /$. It does not appear in the corpus of the older people's messages, and neither do other shortened forms that either match markers from the spoken language, or the usual shortening of lexemes from SMS communication.

We will also list a number of examples in which these forms with omitted vowels appear:

(M2) < Reci cu ti kad da me zoves, msm jos nije nista bilo :P>

("I'll tell you when to call me, I mean nothing's happened yet: $\left.\mathrm{P}^{\prime \prime}\right)$

$<$ Ja sam lupila 3 :-D Nzm dal je tacno :-D >

("I guessed 3 :-D Not sure if it's true :-D")

$<$ Pa meni nista ne znaci da ti se javim ako nmg da te vidim :D>

("Well, it doesn't mean anything for me to call you if I can't see you: D")

$<$ Pa nmzs preko $f b$ da pricas :-D [...] >

("Well, you can't talk via fb :-D [...]")

< Nrv da mogu! -.- i zelim! :p sta ti mislis! :p Ajde bezi tamo! >

("'Course I can! -.- and I want to! : p what do you think! :

p Hey, get off my back!")

$<$ Ali mrm nesto da ucinim!!! [...]>

("But I must do something !!! [...]")

< Hehe ok:) vazi, ja cu vrv biti negde u gradu, pa me ti samo pokupi... >

("Hehe ok :) okay, I'll probably be somewhere in the city, so you just pick me up...")

$<[. .$.$] Aj javi se onda, jedino uvece tj. predvece sam zauzeta danas,$ nmp tacno kad, $[\ldots]>$

("Ok then call me, only in the evening, i.e. I am busy today, have no idea exactly when, [...]") 
Except for msm, used as a discourse marker in the sense of "I mean", other forms are not used as often as their corresponding full forms. It is not entirely clear when they are used, although it seems to us that in some cases the subject matter, the degree of colloquiality and intimacy may influence their usage, especially when other colloquial forms are used in the same message, e.g.:

$$
\begin{aligned}
& <\text { E nzm kuj je izvodjac :-D }> \\
& \text { ("Well I don't know who's the performer :-D") } \\
& <\frac{\text { Ja sam lupila } 3:-D \text { Nzm dal je tacno :- } D>}{\text { ("I guessed } 3:-D \text { don't know whether it's correct :-D") }}
\end{aligned}
$$

In examples like these two, the underlined parts: $k u j>k o j e-$ "who is", ja sam lupila (primary meaning "hit", but here in colloquial figurative meaning "say/guess without thinking") are other "signs" of informality coexisting with shortened forms, thus confirming the "playfullness".

Another tendency that could be suggested for these shortened forms is their discourse position - they occur either in syntactic subordinate clauses, or clauses that express semantically and/or pragmatically an afterthought or additional information, or in responsive messages to some previous messages of the interlocutors:

(M4) < Nzm, koju jaknu? :\&>

("I don't know, which jacket? : \&")

For the sake of comparison we give an example of the use of the full form of the verb znati ("know"):

(M5) < Muzicko treba do baroka, do 25 strane. Ne znam ko se sve javlja za istoriju, ja cu se javiti ako dobro naucim. Mislim da pita latinski, a ne znam da li se nako javlja:D>

("Music should be up to baroque, up to page 25. I don't know who will choose to answer history, I will raise hand if I learn it well. I think she will ask Latin, and I don't know if someone will answer that: D")

When we look at this small number of examples of the form $\mathbf{n z m}$, it seems that it is used to introduce an additional question about an already 
established topic, while $\boldsymbol{n e}$ znam introduces questions that open a new (sub) topic in the last, longer message (M5), which deal with school matters and "official" topics. However, in the correspondence of the same two persons $(\mathrm{O}$ and $\mathrm{P})$ we come across the following variations:

(M6) O: < Jel izlazis? >

(“Are you going out?")

$\mathrm{P}:<N z m$ ti? $>$

(“Don't know, you?")

(M7) O: < Nije, u cetvrtak pita. Izlazis? >

("No, the test is on Thursday. Are you going out?"

$\mathrm{P}:<$ Ne znam, ti? >

("I do not know, you?")

The context is the same - an answer to the question: Are you going out? and an almost identical answer, only in (M6) it is the vowel elision form, in (M7) a full form (although there is an indication that there is a new topic). Therefore, we can assume that the use of these forms, in most cases, takes place on an individual level and as an intersubjective signal of established and familiar topic between peers.

It is worth looking at examples of some more adverbs and adverbial expressions in their shortened versions with omitted vowels:

(M8) < Mogli bi vcrs malo da izblejimo ako nemate sta da radite? > ("We could chill out tonight a little if you have nothing to do"?) < Nemam ni jaaa:( ne seriii, nemoj da places bzvz >

("Neither have meee :( no shiiit, don't cry for nothing")

$<$ Evo bila do kaje sad idem pod tus i u krevet mng sam umorna. [...]> ("Here I come from kaja (proper noun) now taking a shower and to bed so very tired. [...]")

Some of these shortenings appear almost sporadically, while others are more common. If we compare the messages of young people (M) and adults over thirty $(\mathrm{O})$, it can be seen that young people use them much more often. 
Vesna Polovina / Gordana Jelić

Table 2. Shortened and full forms of some other words and expressions in $(\mathrm{M})$ and $(\mathrm{O})$ groups.

\begin{tabular}{|l|l|l|l|l|}
\hline \multicolumn{2}{|l|}{ Shortened form } & Full form \\
\hline$M$ & vcrs & 40 & veceras & 160 \\
$O$ & & - & & 145 \\
\hline$M$ & mng & 3 & mnogo & 100 \\
$O$ & & - & & 83 \\
\hline$M$ & bzvz & 12 & bezveze & 18 \\
$O$ & & 2 & & 3 \\
\hline$M$ & $j b g$ & 85 & jebiga & 8 \\
$O$ & & 8 & & 4 \\
$M$ & $j b t$ & 30 & jebote & 2 \\
$O$ & & - & & 2 \\
\hline
\end{tabular}

Only two words can be accepted as real shortenings, which save the time of writing the message: bzvz ("whatever") and vers ("tonight"). It is not surprising that the short form vers is used quite often, considering that the messages are frequently about planning and arranging meetings, joint outings, etc.

Another difference betweeen younger and older people, obvious from Table 2, concerns the expletive expression jbg ( $>$ jebi ga, in written Serbian often avoided, or signalled by $\mathrm{j} . .$. ga, if necessary)

(M9) < Unutra, ona prva ucionica iz hodnika, poceli smo vec... Jbg, sela ti jedna devojka na mesto... >

("Inside, that first classroom from the hallway, we have already started... Fuck, a girl sat at your place...")

$<$ Jbt gledam gde si, nema te:-D razmisljam dal da te cimam ovo ono... :- $D>$

("Damn it I'm looking where you are, you're gone:

Wondering whether to call you this and that... :-D ") $<$ Znaci kasnim, uzas nema jbng busa, izvinjavam se, ali valjda stizem do 14:45:-(>

("Ok, I'm late, horror no fuckin bus, sorry, but I should be there by $14.45:-(")$ 
It is interesting to note that perhaps the frequency of use also determines the way the "full" form is written. While the members of the older generation write it "correctly" - the verb separated from the object (jebi ga (or some other enclitic pronoun) - "fuck it/you/etc."), the young texters always write it "incorrectly" by writing the verb and the enclitic together. Thus, the awareness of the "non-literal", modal, subjective use of the expressions, and the discourse function of the expressions such as swear words in general, is more clearly emphasized by the way young people write them.

Final elision. The next group of shortenings was created by the so-called final elision, which left either the first syllable plus the initial consonant(s) of the next syllable or the first letter(s) of the word, enough for the word to remain recognizable. Although not so frequent, these shortenings occur in contexts where their meaning is completely clear.

Four groups of such clippings have been singled out: a) those that have a modal meaning: stv > stvarno "really", ustv > ustvari "in fact, actually", ozb > ozbiljno "seriously", b) those related to telephone and internet communication, including verbs: $\mathbf{d o p}>$ dopisivati "writing to someone", odg > odgovoriti "respond", and nouns: por > poruka "message", info $>$ informacija "information", inst > instagram, kr. > kredit "credit", etc., c) greetings and meeting arrangements: $\mathbf{P o z z}>$ pozdrav "greetings", $\mathbf{s l}>$ sledeće "next"), ned $>$ nedelja "Sunday"), and d) more specific clippings used within a certain group of speakers, here high school students (dekl "declension", kol "colloquium", kont "control [test]"), or residents of Belgrade who can recognize that st mercator is actually Stari Merkator "Old Mercator" (a popular name for a part of the city).

The following examples illustrate their use in context:

(M10) a) modal

$<$ Stv? Ja sam videla nesto kao 29. Ali mozda je to bio septembar ahahah $>$

("Really? I saw something like 29. But maybe it was September ahahah")

< Ono bribery league... ja prepisala od tebe danas lista korporacije... a ustv je korupcije jel da? :-D >

("like, bribery league... I copied from you today list of corporations... and it's actually of corruption, isn't it? :-D”) 
Vesna Polovina / Gordana Jelić

$<*$ Lepo i gramaticki ispravno $x D$ ne ozb... >

("* Nice and grammatically correct xD no seriously...")

b) digital communication

$<$ [...] sad mi krivo sto ih nemam na fb:-(Vrv je komendija prava dop. se sa njima:-D>

("[...] now I'm sorry I don't have them on fb :-( Probably great fun messaging with them: -D")

$<$ Jeste od mene poruka, nemam kr. Nista, meni lepo 'vako :-). >

("It is a message from me, I have no credit. Never mind, I feel good like this :-)").

< Pa ja sam ti rekla na ovaj da i saljes i neces pogresiti :) istekle su mi bes.por. $[. .]>$.

("Well, I told you to send it to this one and you won't go wrong :) I've run out of free messages. [...]")

c) greetings and meeting arrangements

$<$ Mare mogu tek od srede, u guzvi sam, a hocemo sto posto da igramo. Pozz>

("Mare I can go only from Wednesday, I'm in a hurry, and we want to one hundred percent. Bye")

< Ma naravno da hocemo ;-) dogovaramo se sl. nedelje, ljubim :-*>

("Of course we will ;-) we discuss that next week, kiss : - *") $<$ Moze ned? >

("Maybe Sunday?")

d) "professional" communication

$<$ Marija nama iz latinskog nije predavala 3 dekl samoglasnicke osnove jel tako? >

("Marija didn't teach us 3 declension with the vowel base from Latin, right?")

$<$ Aj u ponedeljak posle kol da idemo do terazija, a? $M>$

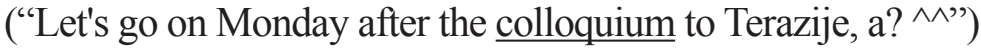

$<$ Ee, Miko, jel nemamo sutra kont. iz informatike? :- $<3>$

("Ee, Miko, don't we have a control (test) in informatics tomorrow?: - I $<3$ ”) 
Most of these examples show that the context in which these clippings occur is sufficient for their understanding. Some have already been used extensively in written language, e.g. dekl in grammars, ned. and other names of days in calendars and timetables. It is the first two groups of clippings that are novel, and especially the b) group of clippings, since they represent the "jargon" of the new medium - phone and internet, digital communication: $\boldsymbol{f b}$, inst, in the form that these loanwords share with the original text messaging English usage, and the Serbian words: dop(isivati), odg(ovoriti) - verbs of communication and nouns $\boldsymbol{k r}$ (edit), por(uka) that have hardly been used in any other domain in which this type of meta-discursive communication is rare. In the first a) group, modal words and expressions, frequently used in spontaneous conversation, are more or less extra-sentential modifiers of utterances, and in speech they can get extra emphasis, as in the $\boldsymbol{S t \boldsymbol { t }}$ ? "Really?" positioned at the beginning of the message as an expression of surprise, or less emphatic as Ne ozb... "No seriously...", in the last example where it follows a compliment and assures that it is truly meant.

By its form, first shortening of a word and then suffixation, a separate group of shortened words were found in the corpus, popular among young people, often called (and criticized) as "youth jargon": mata $>$ mat(ematika) + a, geos $>$ geo(grafija) + os, bios $>$ bio(logija $)+$ os, profa $>$ prof(esor $)+$ a, etc., all of them denoting school subjects or teachers:

(M11) < Prvi cas je geos. :*>

("The first class is geos. : *")

$<$ Duso sta radis, kako ide mata? $<3>$

("Honey, what are you doing, how's maths? $<3$ ")

$<$ E do koje godine imamo bios? :* $>$

("Hey until which year do we have bios? : *")

The examples in (M11) illustrate lexemes that would be pronounced in the same way as they are written: /geos, mata, bios/, while most of the highlighted shortened lexemes in examples (M10) are clippings that occur only in writing, but not in spoken language. 
Even in cases when only the first letter is left, the word is recognizable based on the context (dz-dž(abe), ,free of charge", $\mathbf{z}-\mathrm{z}($ ovi) "call”, $\mathbf{c}-$ ć(ao) - "ciao").

(M12) < Karte su dz, a ne treba ti ni za usput-imam ja ;-) [...]>

("The tickets are free, and no need for money - I have it ;-)

$[\ldots] ")$

$<\boldsymbol{Z}$ me odmah $>$

("Call me at once")

$<$ Vidimo se. Ajde ć :-) >

("See you. Ajde ć :-) ")

In these examples, the first letter refers to recognizable verb of communication, greeting and the expression kupiti/dobiti za džabe - "get / buy something for free", which can sometimes be heard in such a short version even in speech.

Initial and medial elision. We also found initial and medial elision and their combinations. Almost all the cases are shortened forms of words that are transferred from spoken language to the language of short messages, and most often with the aim of creating an atmosphere of informal communication or wit. The first few examples show the omission of the initial sound / $\mathrm{h} /$, which is quite common in Serbian conversational language, and also in some other positions, having to do with the history of this sound (and letter) in the language ${ }^{2}$.

(M13) < Eeeeeee, super! Utorak it is! :-) Ajmo 20h, pa nek bude CD u Evrocentru, ... >

("Eeeeeee, great! Tuesday it is! :-) Let's go at $8 \mathrm{pm}$, so let it be CD in the Eurocentre,...")

$<$ Ajde da ti javim sutra samo da li cetvrtak ili petak>

("Let me tell you tomorrow only whether it's Thursday or Friday")

$<$ Samo to si teo -.. c... >

("That's all you wanted")

2 The orthographic rules of Serbian indicate that the writing of the words that have "lost" this sound in speech, and that occur in majority of Serbian varieties, should follow the etymological principle and be written with an $\underline{\mathrm{h}}$ (Pravopis srpskoga jezika, 2010:30). 
The exclamatory word ajde $>$ hajde ("let's"), shown in context in the first two examples, is used in imperative constructions, and could get imperative verb form suffixes (ajdete, ajmo). These shortened forms are quite frequent in our corpus since they introduce ideas for some action, suggestions, planning in line with the most common topics covered by text messages, whereas the full forms are very rare (around 200 shortened vs. 12 full forms).

The forms like teo/tela, ocu, oces, ("want", "wish") also occur in the corpus, but the use of the full forms hteo/htela, hoces/hocu are more frequent, probably due to the danger of misunderstanding, since they are written without the diacritic when texters use the English keyboard.

The lexeme ladno > hladno ("cold") can be used to refer to real weather conditions or figuratively to the way of behaving/reacting to a situation ("with calm", "showing no nervousness"). Most often, when referring to weather condition or bodily feeling of the speaker, it is used in the full form, while the shortened form is used in figurative meaning.

(M14) < Nisam jos krenula, ali oblacim jaknu, hladno je >

("I haven't started yet, but I'm wearing a jacket, it's cold")

$<$ Koji si smarac, 'ladno spavas :-P>

("What a lazy bones you are, you sleep as you care for nothing: - P")

Occasionally, a colloquially shortened, substandard version of an interrogative, question form occurs in the corpus. The auxiliaries: $c u, s i$ in the next examples occupy the first position in the sentence, which is highly substandard, against the rules of standard Serbian where the enclitic forms like these must be in the second position in a sentence. This type of elliptical construction belongs more to the syntactic level of analysis, as described in Jelić and Vekarić (2020), but it can be further combined with some shortened word forms.

(M15) < Meni poslao. I to rar file. $\boldsymbol{C u}$ ti prosledim i to... >

("He sent it to me. And as a rar file. I'll pass that on to you ...") $<$ Si vido prognozu? >

("Did you see the forecast?")

$<$ E si kuci? >

(“Are you home?") 
In the last example: $\boldsymbol{E}$ si $\boldsymbol{k u c i}$ ? Are you home? it is even possible to interpret that $\boldsymbol{E} \boldsymbol{s i}$ as the shortened form of the full verb jesi / j /, or as an exclamation word ej combined with the substandard si, similar to the following case:

(M16) < E sa rais? Ono... sutra bi mogli da se vidimo.. ili prekosutra.. Sta mislis?>

("Hey, wha'u doing? Now... we could meet tomorrow .. or the day after tomorrow .. What do you think?")

$<$ Hahahahah bolje nego mene hahahah zahvaljujem na tome! Ne sumnjam da bi bilo tako :) psihicki si raznezen?? Si to reko? So? :) >

("Hahahahah better than me hahahah thank you for that! I have no doubt that would be the case :) you mentally weak ?? Did you say that? Why? :)")

The interrogative pronouns sa > šta "what", So > što "what, why" are also highly colloquial when compared to examples of $/ \mathrm{h} /$ elision that are more frequent and more of a norm in spoken language. Similarly, our next examples of medial shortening could be classified as highly marked forms of spontaneous substandard pronunciation in spoken Serbian: neam $>$ nemam "I don't have" mos > možeš "you can"; os > hoćeš "you want/ will", vim > vidim "I see", vis > vidiš "you see".

(M17) < Neam pojma sad cu sa comi da se dog.. >

("I have no idea now I'm going to happen with you ..")

$<$ Gotova sam mos misliti :-D 3 str. Kraj je najbolji hahah e ako me posle ovoga ne izaberu... e onda stvarno ne znam koga ce :-D > )

("I'm ready you can imagine :-D 3 p. The end is the best hahah, if they don't choose me after this, then I really don't know who they will :-D")

< Os da sedis jos kod gaje da dodjem el da dodjete do mene? >

("Will you be still sitting at gaja's do I come or you come to me?")

3 These might be seen as mistakes in typing, but then there would be too much consistency in making such mistakes by different texters, or one would expect at least an occasional repair either by a sender or a receiver of the messages (as shown by Jelić and Polovina, 2015) 
$<$ Ma pitam onako, vim ne pominjes. Pa ako vec nemas sta da radis tu onda idi iskoristi da se vidis s njima nisi mi reko os od nedelje neki dan da se vidimo? >

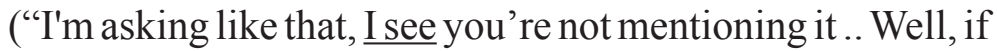
you've nothing to do there then make the most of it to see them didn't tell me if you will that we meet sometime from Sunday on?")

$<$ De nije..vis kolko je toplo.. Oke ;) >

("Come on, you see how warm it is .. Okay;")

The use of these forms with initial and medial elision not only reflects possible pronunciation in conversation, which would, in most cases, be heard without any nuance of "playfullness", but in the written form they give an extra level of markedness so it is this marked transfer from spoken language into the written texts that adds the nuance of "playfullness" to the messages.

Standard abbreviations. The texters also use existing abbreviations in the Serbian language, mainly used in other written genres, such as: $n p r, i t d, b r, t e l, g, u l$, etc., i.e., prof, gdjo, min, ps, $t v$; then abbreviations for cities and countries, such as $\boldsymbol{b} \boldsymbol{g}, \boldsymbol{n b g}, \boldsymbol{n s}, \boldsymbol{g m}$ (Gornji Milanovac), ja (Jagodina), va (Valjevo); slo (Slovenia), mne (Montenegro), cro (Croatia).

(M18) < Kupite malo hleba, npr. lepinju. I novine. >

("Buy some bread, e.g. bun. And newspapers.")

$<$ Taj vas posao zlata vredan....-)[...]:-) Umem $i$ da kopiram, kucam, cistim... itd... :-)>

("That job is worth gold... :-) [...]I can also copy, type, clean... etc... :-)")

< Mozda bi bilo bolje pre. Ja cu ujutru rano doci na NBG, [...] >

"(Maybe it would be better sooner. I will come to $\underline{\mathrm{NBG}}$ early in the morning, $[\ldots]$ ")

$<$ Kad putujete za Cro? >

("When are you travelling to $\underline{\text { Cro }}$ ?")

Borrowing of English clippings. Given the fact that there are a large number of abbreviations used in English in short messages, and the 
high frequency of use of English in young people's speech in general, the analysis revealed somewhat unexpected results showing very little use of abbreviations taken from English.

(M19) < Napisi msg >

("Write a msg")

$<$ Jeeeeeeste, moramo da ponovimo asap, ali sa Dacom ;-) Btw, $i$ ja kasnila na pos'o jutros, isto mi se spava do jaja, udavicu nekog $\therefore-D>$

("Jeeeeeeste, we have to repeat it asap, but with Daca ;-) $\underline{B t w}$, I was late for work this morning, I also feel sleepy, I will strangle someone :-D")

$<$ Ma cula si 100\% bree! Meni je ok ime.. I ja tebeeee $<3<3>3>$

("You heard $100 \%$ c'mon! The name is ok .. Youuuu too $<3<3>3$ ")

$<$ A neeeeeemoj ljutis pls .... Pa stvarno ne znam ni kada cu doci kuci... try to understand me :) ... P $\boldsymbol{P} \boldsymbol{S}>$

("And do nooooot be angry pls.... Well, I really don't even

know when I'll be home... try to understand me :)... PLS") $<$ Evo me nafb-u :-D>

("Here I am on $\mathrm{fb}:-\mathrm{D}$ ")

< Omg omg!!! Red alarm!!! Luka popizdeo, zove Petra... javljam detalje... na sms ili na gmail/gtalk? >

("Omg omg !!! Red alarm !!! Luka freaked out, calling Petra... I'm reporting details... on sms or on gmail / gtalk?”)

Of all the borrowings of English clippings and abbreviations that can be found in our corpus, only fb occurs in more than a dozen examples, while the others appear 3, 4, 5 times in the corpus, and they may be individual choice of some of the texters.

The use of logograms. The examples of the use of logograms in word shortening, and graphological innovations are rare. We have found only the following examples: u3povala > utripovala "imagined" as a slang word, o5 > opet, "again", laq noc > laku noć, "good night", frx : frka/ frci "mess". This again shows that homonymy in Serbian simply does not include cases of frequent expressions for users of text messaging to create 
rebus-like shortenings with other symbols (excluding the emoticons, symbols for kisses, etc.)

Conclusion. Some authors (Crystal, 2008; Tagg, 2009) cite many more examples of word shortening in their analyses of short messages in English, and link their existence to the need for concise linguistic expression. However, since English has much more homonymy between some frequent words, numbers and spelling (four / for, two / to, CU / see you, etc.) than is the case with some other languages, it is not unexpected that shortenings and clippings used in other languages also differ both in their frequency and type. In the case of Serbian, it seems that the reasons are not so much a concise linguistic expression, except in the case of "standard" shortenings (the ones long established in the written language), but the need for informality of communication which implies a close interpersonal relationship between interlocutors. This conclusion can be confirmed again by looking at some more examples.

(M20) < Al pazi da je ne zagubis... ja cu te cim al ti moras tog trena da iskocis nemo posle bude u sred sam partije. >

("But be careful not to lose it... I'll call you but you must get out at once let it not be I'm in the midst of the game.") < Mikoooooo, de si, si dobro? Nista nisi odgovorila juce: [...] >

("Mikoooooo, where are you, are you okay? You didn't answer anything yesterday: [...]")

$<$ Mile ocu didem samo me pozovi desetak min pre nego sto podjemo.. [...] >

("Mile I wanna go just call me about ten minutes before we leave .. [...]")

These examples illustrate at least 3 mixed types of shortenings: final elision - al $>$ ali, $\boldsymbol{c i m}>$ cimnuti "lit. pull, fig. call", nemo $>$ nemoj "let it not"; initial elision $\boldsymbol{d e} \boldsymbol{s i}>$ gde si, plus si (dobro)> jesi (dobro); initial and medial elision in ocu didem > hocu da idem "I wanna go".

In addition to the fact that some of the shortenings transferred from the colloquial spoken language in general reflect an informal relationship between interlocutors, message writers sometimes establish a marked jovial type of communication, by using elliptical constructions and forms that 
almost never, not even in literary work (that might imitate conversational, dialectal, informal language) appear in written form. Some of our examples of initial and especially medial elision: rais ( $>$ radiš), vim ( $>$ vidim), sa ( $>$ šta), so (što) etc., do occur in spoken language, but do not get perceived as jovial and humorous as much as when they are written down in a text. Serbian texters therefore can upgrade the degree of "playfulness" by using such shortened forms.

Some shortenings add a different kind of meaning change. This refers to shortenings and abbreviations such as: $m s m, j b g$, ozb, which function as discourse markers, different from their primary meaning as verbs or adverbs. A similar change is exemplified by the lexeme ladno - hladno in primary and figurative meaning. The young texters tend to write them in accordance with the different meaning - writing them in shortened version when discourse or figurative meaning is different from the basic, primary meaning. This shows that the young speakers of Serbian are implicitly aware of the different semantic value of the shortened form in relation to the full form of a word or phrase.

The discourse of messages shows similarity with written language by using standard abbreviations (e.g. dekl, BG, Cro, etc.). Some further shortenings and abbreviations are characteristic almost exclusively for communication by SMS messages: vcrs, dog, $z, f b, k r$. etc. They belong mainly to the group of vowel elision and final elision, and such shortenings can be explained by the need for language economy, saving on the time for typing a word that is too long ( $v c r s)$, frequent $(f b)$ or completely predictable in a given context $(d z, k r$.) (collocational predictability - karte su $d z$ or the context of text messaging in general - nemam $\mathrm{kr}$ ). Frequency of use (vcrs, $b z v z$ ), typicality of the topic - communication, agreements, allow the use of some abbreviations, especially since they rarely occur at the beginning of communication, but usually in a responsive message.

Concerning the functioning of shortened forms in the discourse of text messaging, we did not compare the relationship between shortening and lengthening of words and other elements in messages, for example:

(M21) < Jel mozes samo da mi das fiksni, ako nije problem, posto nemam vise minuta $<3$ Hvala ti puno $\leq 3<3<3<3<3<3$ ?!?!?!? $>$

("Can you just give me a fixed, if not a problem, since I don't have more minutes $<3$ Thank you very much $\leq 3<3<3<3<3$ ?!?!?!?") 
$<$ Jel lep ?!?!?!?>

("Is it beautiful ?!?!?!?")

In both of these examples, emoticon symbols and punctuation marks (underlined parts) are made more prominent by lengthening and they occur in the same messages as the shortened forms. In order to talk about degrees of exressiveness it would be interesting to compare what roles either of the phenomena fulfil and what their combinations mean for the texters.

There is also an important question about the relationship between full forms and shortenings. We have given comparison of some of the shortenings in relation to the full forms, but some further research should go into that question even more deeply. In principle, some common shortenings are not used frequently at all. Messages:

$(\mathrm{M} 22)<$ E do koje godine imamo bios? :*>

("Until what year do we have bios? : *")

$<$ Dobila sam 5 iz srpskog!!!!!!! >

("I got 5 from Serbian !!!!!!!")

do not contain a possible shortening of the lexeme godine (year) or srpski (Serbian, as a subject in school). The use of full forms certainly more clearly emphasizes the importance of these items for statements, and here it would be unusual to see them in shortened forms.

To sum up, the process of shortening in text messaging is worth investigating since it shows that the texters, especially young ones, recognize and use an aspect of word creation with subtle sensitivity for their mother tongue and that this specific type of discourse offers insight into innovative uses of language through shortening and clipping. 
Vesna Polovina / Gordana Jelić

\section{REFERENCES:}

Bauer, L. (2004) Morphological Productivity. Cambridge: Cambridge University Press.

Bieswanger, M. (2007) '2 abbrevi8 or not 2 abbrevi8: A Contrastive Analysis of Different Space- and Time-Saving Strategies in English and German Text Messages'. V: Hallett, T., Floyd, S., Oshima, S., \& Shield, A. (Ed.): Texas Linguistics Forum, vol. 50, Austin: University of Texas.

Blasco, M. et C. Bodelot (2017) Langue parlée / langue écrite, du latin au français : un clivage dans l'histoire de la langue ?, Langages, $4 \mathrm{~N}^{\circ} 208,5-16$.

Crystal, D. (2001) Language and the Internet. Cambridge: Cambridge University Press.

Crystal, D. (2008) Txtng: the Gr8 Db8. Oxford: Oxford University Press.

Denis Jamet (2009) A morphophonological approach to clipping in English, Lexis [Online], HS $1 \mid$ 2009. 15-31.

Gonzales, F.R., Fajardo, J.A.S, (2018) Morpho-syntactic variation in English and Spanish clipped words: a contrastive study. Zeitschrift fur romanische Philologie. Vol. 134/3. De Gruyter. 734-760.

Jelić, G. i Vekarić, G. (2020) 'Elliptical constructions in SMS communication'. M. Matešić i B. Martinović (ur.) Značenje u jeziku - od indvidualnoga do kolektivnoga. Zagreb: HDPL i Srednja Europa. 89-102.

Jelić, G. (2015) Lingvistička obeležja i diskursna struktura kratkih poruka u mobilnoj telefoniji (neobjavljena doktorska disertacija), Beograd: Filološki fakultet.

Jelić, G. i V. Polovina (2015) Samoispravka i ispravka u jeziku kratkih poruka. Anali Filološkog fakulteta, Beograd: Filološki fakultet. 27/2: 406-423.

Jovanovic, V. Ž. (2014) 'Marginalization of Linguistic Form for Effective Communication: Morphological Issues in English and Serbian', in: Language, Literature, Marginalization, Niš: Filozofski fakultet, 355 - 372.

Ling, R. (2005) 'The socio-linguistics of SMS: An analysis of SMS use by a random sample of Norwegians.' in Mobile communications: Renegotiation of the social sphere, edited by R. Ling and P. Pedersen. London: Springer $335-349$.

Mel'čuk, I. (2006) Aspects of the Theory of Morphology. Berlin-New York: Mouton de Gruyter.

Plag, I. (2002) Word-formation in English. Cambridge: Cambridge University Press.

Polovina, V. (2019) Signali diskursa. Beograd: Filološki fakultet. 
Radić-Bojanić, B. (2007) Neko za chat?! Diskurs elektronskih ćaskaonica na engleskom i srpskom jeziku. Filozofski fakultet: Futura publikacije. Novi Sad.

Tagg, C. (2009) A Corpus Linguistics Study of SMS Text Messaging. Ph.D. dissertation, University of Birmingham.

Zwicky, A.M. and G.K. Pullum (1987) Plain Morphology and Expressive Morphology. Proceedings of the Thirteenth Annual Meeting of the Berkeley Linguistics Society. 330-340.

Пешикан, М. и др. (2010) Правоӣuс срӣскоїа језика. Нови Сад: Матица Српска

\section{Vesna Polovina \\ Gordana Jelić}

\section{SKRAĆENICE U SRPSKIM SMS PORUKAMA}

\section{Sažetak}

Analiza skraćivanja reči i izraza u SMS porukama u srpskom jeziku zanimljiva je sa sociolingvističkog stanovišta. Skraćenice se, naime, smatraju istaknutim obeležjem ove vrste tekstova koje se često kritikuje jer se smatra da utiču na nivo pismenosti kod mladih. Sa opštelingvističkog stanovišta interesantno je razmotriti u kojoj meri se stvaraju nove reči u toj vrsti komunikacije, a još je važnije utvrditi kako takve skraćenice funkcionišu u diskursu. Većina analiziranih slučajeva pokazuju da upravo mladi više koriste skraćene oblike reči, ali je ta upotreba u dobroj meri u skladu sa spontanim usmenim jezikom i upotrebom skraćenih oblika kako je propisano pravopisnim pravilima, nego što se javljaju neki devijantni, nepravilni oblici skraćivanja. Naprotiv, mnoge od tih skraćenica imaju ulogu obeležavanja odnosa u grupi, među prijateljima, ispoljavajući neformalnost spontane svakodnevne komunikacije, a vrlo često pokazuju dobar osećaj za srpski jezik kroz implicitno znanje o upotrebi skraćenica u specifičnom diskursu SMS poruka.

Ključne reči: SMS poruke, srpski, skraćenice, elizija 